www.jmscr.igmpublication.org

Impact Factor 5.84

Index Copernicus Value: 83.27

ISSN (e)-2347-176x ISSN (p) 2455-0450

crossref DOI: _https://dx.doi.org/10.18535/jmscr/v5i5.160

\title{
Enterococcus hirae, Unexpected Bacteria Detected in Rectal Swab of A Subject in Nduga District, Papua Province by 16s rDNA Sequencing System
}

Authors

\section{Hotma Martogi Lorensi Hutapea, Ratna Tanjung, Vatim Dwi Cahyani, Yustinus Maladan, Hana Krismawati, Antonius Oktavian}

Institute of Research and Development for Biomedicine Papua, Jl. Kesehatan No.10 Dok II, Jayapura 99112, Provinsi Papua, Indonesia

\section{Abstract}

Enterococci are opportunistic pathogens known as a significant cause of nosocomial and communityacquired infections. Enterococcus faecalisand E. faeciumare the most common species identified in this infection. Another species, E. hirae is known to infect animals, and rarely isolated from human. The goal of this study was to characterize Enterococci derived a4 years old female rectal swab. The characterization was performed using MicroSeqID ${ }^{T M} 500$ sequencing system. DNA genomic was extracted from single colony and characterized using MicroSeqID ${ }^{T M} 500$ system. The sequence data was analyzed by homology analysis to MicroSeq library ${ }^{T M}$, genbank, and phylogenetic. The sequencing results showed that the isolate highly homolog to Enterococci sp. Phylogenetic analysis of $16 \mathrm{~S}$ rDNA showed that the isolate was closely related to Enterococcus hirae.

Keywords: Enterococci, Enterococcus hirae, MicroseqID ${ }^{T M} 500,16 \mathrm{~S}$ rDNA.

\section{Introduction}

Nowadays, Enterococci infection has been a concern with the emergence of vancomycinresistant strains especially in E. faecalis and E.faecium. The reported enterococci infection was mostly caused by E. faecalis and E.faecium, but the infection caused by E.hirae in human is rarely reported. ${ }^{1,2}$ However, all reported cases involved bacteremia with severe illness. There are 12 reports associated E.hirae infection in human during 1998-2016. In the older literature, E.hirae (Farrow and Collins 1985) is mentioned as minority population of human intestinal flora, based on its habitat, albeit rarely.
The colony morphology of E.hirae is identical to another Enterococci. Several microbiology assay should be performed to identify the E.hirae colony. The 16S rRNA gene sequencing is one of the useful technique to simplify the E.hirae detection in a specimen. The $16 \mathrm{~S}$ rRNA itself is essential in bacteria since it presents in almost all bacteria and its function has not changed overtime, suggesting that changes are accurate measure of time. ${ }^{3}$ MicroSeq $\mathrm{ID}^{\mathrm{TM}}$ is one of the sequencing technique developed to identify the bacterial isolates another commercial system failed to identify correctly. ${ }^{4}$

The Nduga Regency is one of the most remote area in the central highlands of Papua Province. 
The population mostly consists of indigenous Papuans living in small villages like Mbua, Dal, and Mbulu Yalma. The accessibility of the transportation is restricted due to primary mountain rainforest surrounding the area. Health care centers and adequate health care personnel are not functioning completely due to the cultural, behavior and difficult transportation access. The people of Mbuwa village do not aware of disease and sickness. It indicates that the people of Nduga Regency do not aware about healthy behavior concept. The infection of bacteria is common in the Nduga Regency population since they were not covered by vaccination. ${ }^{5}$

The lack of vaccination coverage increases the opportunity of bacterial infection in children. Enterococci is one of the pathogen which is common found in children. The infection of this bacteria used to be thought as unimportant medically, however as the technology develop, Enterococci was found as the most common pathogen that causes nosocomial infection with $61 \%$ of death. ${ }^{6}$ Enterococcus hirae infection is common in human and birds, but rarely isolated from human. ${ }^{7}$ E.hirae infection was confirmed as the cause of diarrhea in rats on day two to six days after inoculation. ${ }^{8}$ Many studies showed that the transmission of $E$. hirae from animal to human and human to animal is possible. ${ }^{9,10}$ The incident number of E. hirae infection is the lowest, 1-3\% of Enterococci infection. E. hirae is bacteremia, and associated to kidney diseases, endocarditis, spondylodiscitis, pyelonephritis, and cirrhosis. ${ }^{1,2}$ E. hirae is also reported causing urinary tract infection $^{7}$. Short communication published by Vincenzo et al. on 2013 showed that E.hiraeis isolated from the blood of umbilical cord of a giving birth mother. ${ }^{1}$ There is no published data about $E$. hirae infection from rectal swab in adults or children in Indonesia, especially in Papua.

\section{Method}

Genome preparation

A rectal swabs was collected from 4 years old female (coded as $15 \mathrm{RS}$ ) with diarrhea symptom in
Mbua village. The swabs were directly stored into PBS prior to bacterial culture. The swabs were streaked onto Nutrient Agar and incubated at $37^{\circ} \mathrm{C}$ for 24 hours. The morphology of colonies were recorded. The colonies were subculture onto another Nutrient Agar. The genome were isolated from single colony prior to sequencing procedure. The sequencing was performed by using MicroSeq $\mathrm{ID}^{\mathrm{TM}}$. The genome isolation was performed by applying $100 \mu \mathrm{l}$ PrepMan $^{\text {TM }}$ (Applied Biosystem) on $1 \mu 1$ loop colonies. The reaction was incubated for 10 minutes at $100^{\circ} \mathrm{C}$. The obtained genomic DNA were diluted 100 times. Biochemical assays were not performed in this study.

16S rDNA PCR, the purification, and cycle sequencing PCR

DNA amplification was performed by applying 15 $\mu 1$ FAST MicroSeq ${ }^{T M}$ 16S rDNA PCR master mix (Applied Biosystem) and $15 \mu 1$ genomic DNA. The purification of the PCR product was conducted using $15 \mu \mathrm{l}$ of ExoSAP-IT ${ }^{\circledR}$ and $12.5 \mu 1$ of PCR product. The reaction was incubated at $37^{\circ} \mathrm{C}$ for 15 minutes and $80^{\circ} \mathrm{C}$ for 15 minutes. The cycle sequencing PCR was performed on $13 \mu \mathrm{l}$ MicroSeq $^{\text {TM }} 500$ 16S Forward Sequencing Mix, $13 \mu 1$ MicroSeq $^{\text {TM }} 50016$ S reverse Sequencing and $7 \mu 1$ of purified PCR product. The purification of cycle sequencing PCR product was performed by using Performa DTR Filtration Catridge. The pure cycle sequencing products were applied to capillary electrophoresis by using $\mathrm{POP}^{\mathrm{TM}}$ as the polymer.

\section{Data Analysis}

Sequences consensus were generated and referred automatically by the MicroSeq Library. The sequence identification were also performed manually by submitting the sequence to genbank. The phylogenetic tree was automatically constructed by MicroSeq ID v.30, and confirmed by MEGA 5. 


\section{Results}

Morphology

Bacterial colony were appeared uniformly on Nutrient Agar, cream in color, and $1.5 \mathrm{~mm}$ in diameter. The colony was smooth, the margin was entire, and surface was raised. Enterococci coloniesare identical to each other, so that colony appearance does not represent the species (Figure 1). Enterococci identification can be performed accurately by applying molecular biology technique. $^{11}$

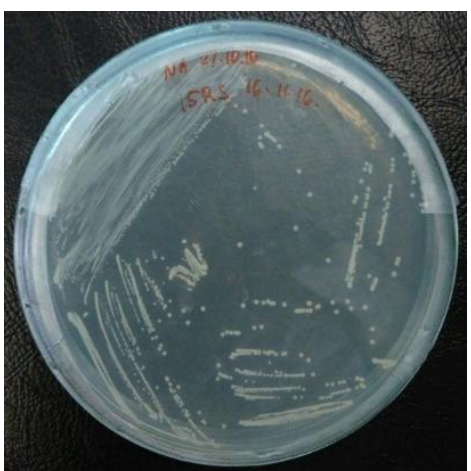

Figure 1. Enterococci colonies appearance on Nutrient Agar

Nucleotide sequence analysis

The nucleotide sequences were automatically retrieved from the Microseq ID library and aligned to the 7 sequences as the closest reference for each specimen. The analysis showed that colony 25 from sample 15RS was identified as Enterococcus (table1).

Table 1. The colony identification based on 16S rDNA analysis

\begin{tabular}{|c|c|c|c|}
\hline No. & $\begin{array}{l}\text { Specimen } \\
\text { Code }\end{array}$ & Library Entry Name & $\begin{array}{c}\% \\
\text { Match }\end{array}$ \\
\hline \multirow{7}{*}{1.} & \multirow{7}{*}{$15 \mathrm{RS} / 25$} & Enterococcus hirae $($ ATCC $=8043)$ & 99.99 \\
\hline & & Enterococcus hirae $(A T C C=10541)$ & 99.78 \\
\hline & & Enterococcus faecium $(A T C C=19434)$ & 99.74 \\
\hline & & Enterococcus durans $(A T C C=19432)$ & 99.35 \\
\hline & & Enterococcus canis $(C C M=7125)$ & 98.57 \\
\hline & & Enterococcus villorum $(C C M=4887)$ & 98.14 \\
\hline & & Enterococcus thailandicus (DSM=21767) & 98.03 \\
\hline 2. & $\begin{array}{l}\text { Positive } \\
\text { control }\end{array}$ & Escherichia coli $(A T C C=11303)$ & 100 \\
\hline
\end{tabular}

Sequencing result was automatically analyzed by using MicroSeqID ${ }^{T M} 500$ by aligning the sample DNA sequence to 7 closest $16 \mathrm{~S}$ rDNA sequence in the library of the software. The alignment data showed that the specimen was highly homologue to Enterococci (98.03 - 99.99\%), especially to $E$. hirae (99.99\%). The phylogenetic analysis result confirmed that specimen code 015 was closely related to E. hirae.

The phylogenetic analysis retrieved from MicroSeqID ${ }^{T M} 500$ software also showed the $16 \mathrm{~S}$ rDNA sequence from colonynumber 25 (Figure 2 ). It showed that the colony number 25 had the nearest distant to E.hirae (ATCC $=8043$ dan 10541) compare to another Enterococci species.

Specimen : 25 \lrcorner$=0.2897 \%$

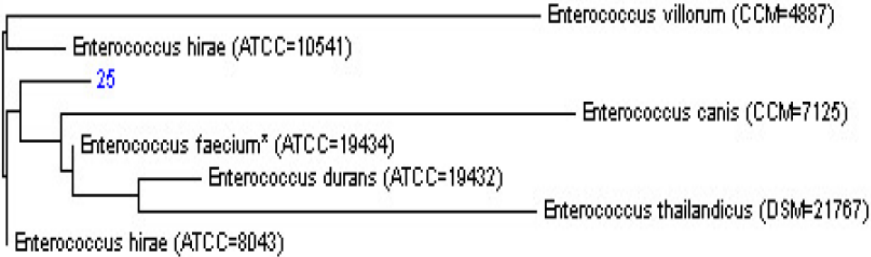

Figure 2 Phylogenetic analysis result retrieved from MicroSeqID ${ }^{\mathrm{TM}} 500$ software

The similar result was obtained when the phylogenetic analysis was performed by using MEGA 5.1. Colony number 25 was identified as E.hirae (Figure 3).

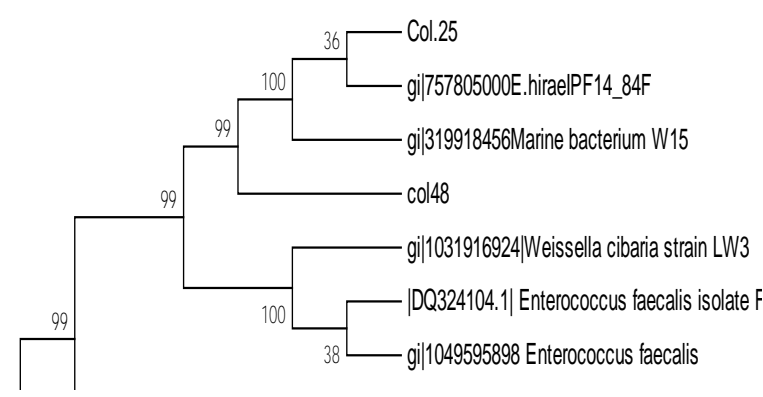

Figure 3 Phylogenetic Analysis byusing MEGA 5.1

\section{Discussion}

Apart from environmental condition, the report of E. hirae infection in human also is associated to highly active human-animal interaction, especially humanto pig. ${ }^{12,13}$ The $16 \mathrm{~S}$ rRNA sequencing is very useful to determine the species of bacteria including Enterococci. ${ }^{14}$ Enterococci used to be assumed as normal intestinal flora, and when isolated from stool or rectal swab of a human, it was considered as harmless and unrelated to the 
diarrheal illness. However, study conducted in Taiwan, France, and Korea showed that $E$. hiraeinfection is related to cholecystitis, cirrhosis, and pancreatitic. ${ }^{1,9}$ In a studies showed that Enterococci have been considered as one of many cause of diarrhea in animals, ${ }^{8,13}$ but there are no data available related to E.hirae and diarrhea in human.The available reports in literature show that the infection by $E$. hirae is life threatening., ${ }^{1,2}$ In this study, E. hirae infection was detected in 4 years old female with diarrhea.A deep clinical examination to study the systemic diseases was not conducted to the subject due to the health facility limitation.

Enterococcus species is able to colonize the gastrointestinal tract as its normal habitat, and able to adhere to many extracellular matrix proteins, epithelia, and cells. Colonisation in gastrointestinal may not constitute a virulence factor, but it amplifies the potential pathogenicity of a strain in combination with other virulence factors, and the specificity of host tissue. Most infection of Enterococcus species is endogenous by translocatingthe bacteria through the epithelial cells of the intestine, causing the bacteria spread to other cells within the body. ${ }^{15}$ When the bacteria is detected outside the gastrointestinal tract, the infection of $E$. hirae manifestation is in cardiovascular system, musculoscletal system, and urinary system and end up to shock septic.

The ability of enterococcito migrate from digestive system to blood is a concern since these pathogens represent the difficult-to-treat agents of diseases once administered in blood system. The native valve endocarditis in 72 year old man is confirmed caused by E. hirae. The patient is clinically well 6 months after receiving intravenous therapy with vancomycin and gentamicin for 6 weeks, followed by oral amoxicillin (6 g per day) for 8 weeks. ${ }^{11}$ A short communication reported by Saviniet al. on 2013 showed that E.hirae capable of contaminating the umbilical cord blood (UBC). In this case, the donor is presumed acquired colonization from pets, like cats, birds, and turtles. ${ }^{10}$
In this study, subject was living in a honai (traditional housing of Papua) together with the family member and their pet animal. The air ventilation of the honai was poor, and the light intensity is low. The cooking activity was inside the honai and involving log. The consumed water was from the same source where pet animal drink. The common pet animal in this village was piglet. ${ }^{5}$ The condition of the environment of the subject may be potential as the transmission of the pathogen of animal diseases from animal to human like E. hirae.

\section{Conclusion}

It is necessary to do the examination to ensure the effect of $E$. hirae infection in the subject, considering its factors of virulence and pathogenesis.

\section{Acknowledgement}

Acknowledment for Dinas Kesehatan Provinsi Papua, Dinas Kesehatan Kabupaten Nduga, dan Tim Gerak Cepat Kementerian Kesehatan RI

\section{Conflict of Interest}

The authors declare that there is no conflict of interests regarding the publication of this paper.

\section{Reference}

1. Dicpinigaitis P V, Aguirre M De, Divito J. Enterococcus hirae Bacteremia Associated with Acute Pancreatitis and Septic Shock. Hindawi.

2015:5-8. doi:10.1155/2015/123852.

2. Devriese LA, Vancanneyt M, Descheemaeker P, et al. Differentiation and Identication of Enterococcus durans, E. hirae and E. villorum. J Appl Microbiol. 2002;92:821-827.

3. Janda JM, Abbott SL. 16S rRNA Gene Sequencing for Bacterial Identification in The Diagnostic Laboratory: Pluses, perils, and pitfalls. $J$ Clin Microbiol. 2007;45(9):2761-2764. doi:10.1128/JCM.01228-07. 
4. Woo PCY, Ng KHL, Lau SKP, et al. Usefulness of the MicroSeq 500 16S Ribosomal DNA-Based Bacterial Identification System for Identification of Clinically Significant Bacterial Isolates with Ambiguous Biochemical Profiles. J Clin Microbiol. 2003;41(5):1996-2001. doi:10.1128/JCM.41.5.1996-2001.2003.

5. Tim Gerak Cepat Kementerian Kesehatan Republik Indonesia. Laporan Verifikasi Kasus Kematian Balita Oleh Sebab Yang Belum Diketahui Di Kecamatan Mbua Kabupaten Nduga Provinsi Papua.; 2015.

6. Fisher K, Phillips C. The ecology , epidemiology and virulence of Enterococcus. 2016;(2009):1749-1757. doi:10.1099/mic.0.026385-0.

7. Bourafa N, Loucif L, Boutefnouchet N. Enterococcus hirae, An Unusual Pathogen in Humans Causing Urinary Tract Infection in A Patient with Benign Prostatic Hyperplasia: First Case Report in Algeria. New Microbes New Infect. 2015;8:7-9. doi:10.1016/j.nmni.2015.08.003.

8. Etheridge ME, Yolken RH, Vonderfecht SL. Enterococcus hirae Implicated as a Cause of Diarrhea in Suckling Rats. J Clin Microbiol. 1988;26(9):1741-1744.

9. Pãosinho A, Azevedo T, Alves J V, et al. Case Report Acute Pyelonephritis with Bacteremia Caused by Enterococcus hirae: A Rare Infection in Humans. 2016;2016:10-13.

10. Savini V, Bonfini T, Marrollo R, et al. Enterococcus hirae: A Zoonotic Microorganism in Human Umbilical Cord Blood. World J Microbiol Biotechnol. 2013. doi:10.1007/s11274-013-1537-4.

11. Talarmin JP, Pineau S, Guillouzouic A, et al. Relapse of Enterococcus hirae Prosthetic Valve Endocarditis. J Clin Microbiol. $\quad 2011 ; 49(3): 1182-1184$. doi:10.1128/JCM.02049-10.
12. Franz CMAP, Holzapfel WH, Stiles ME. Enterococci at the crossroads of food safety? Int J Food Microbiol. 1999;47:124.

13. Lapointe JM, Higgins R, Barrette N, Milette S. Enterococcus hirae enteropathy with ascending cholangitis and pancreatitis in a kitten. Vet Pathol. 2000;37(3):282284. doi:10.1354/vp.37-3-282.

14. Patel R, Piper KE, Rouse MS, et al. Determination of $16 \mathrm{~S}$ rRNA Sequences of Enterococci and Application to Species Identi cation of Nonmotile. Society. 1998;36(11):3399-3407.

15. Fisher K, Phillips C. The ecology , epidemiology and virulence of Enterococcus. Microbiology. 2009;(155):17491757. doi:10.1099/mic.0.026385-0. 